\title{
Nadvojvoda Evgen 1863-1954
}

\section{IZVLEČEK}

Avtor v članku Nadvojvoda Evgen 1863-1954 obravnava osnovno biografsko skico nadvojvode Evgena od njegovega rojstva do prvih mesecev po vstopu Kraljevine Italije v prvo svetovno vojno. Nadvojvoda Evgen je bil rojen leta 1863 in je pripadal habsburški dedni hiši. V toku svojega življenja je zgradil izjemno vojaško kariero, ki je dosegla svoj vrhunec v času prve svetovne vojne. Nadvojvoda Evgen je namreč po odhodu Oskarja Potioreka z mesta poveljnika avstro-ogrske vojske na Balkanu postal njegov naslednik. Na tem položaju je ostal do maja leta 1915, ko je Kraljevina Italija vstopila v vojno. V tistem trenutku je nadvojvoda Evgen postal poveljnik novoustanovljenega poveljstva jugozahodne fronte. Iz slovenske perspektive je to dejstvo pomembno ne samo zato, ker je pod to poveljstvo spadalo tudi bojišče ob Soči, ampak ker je bilo poveljstvo jugozahodne fronte med majem 1915 in marcem 1916 in nato še od marca 1917 do novembra 1917 nastanjeno $v$ Mariboru. Mesto ob Dravi je s prisotnostjo tako visokega in za naše dežele izredno pomembnega poveljstva $v$ času vélike vojne doseglo v primerjavi z drugimi slovenskimi mesti izjemen položaj. Nadvojvoda Evgen in sirši javnosti morda bolj znani Svetozar Boroević de Bojna tako predstavljata ključni osebi pri organizaciji in izvedbi vojaških akcij na soškem bojičču. Temelj pričujočega članka predstavlja predstavitev vojaške kariere nadvojvode Evgena, ki ga je pripeljala do zasedbe pomembnega položaja od začetka prve svetovne vojne naprej. Hkrati pa pričujoči članek predstavlja osnovo za nadaljnje raziskovanje delovanja nadvojvode Evgena v času prve svetovne vojne.

Ključne besede: nadvojvoda Evgen, prva svetovna vojna, soška fronta, poveljstvo jugozahodne fronte, Maribor

\section{ABSTRACT \\ ARCHDUKE EUGEN 1863-1954}

In the article Archduke Eugen 1863-1954 the author deals with the basic biography of Archduke Eugen from his birth until the first months after the Italian involvement into World War I. Archduke Eugen was born in 1863 as a member of the Habsburg dynasty. During his lifetime Eugen achieved a magnificent military career, culminating during the World War I. In fact, after Oskar Potiorek had left the position of the Commander of the Balkan Army, Eugen became his successor. Archduke Eugen remained in this position until May 1915, when Italy entered the war. At this time he became the Commander of the newly-established Command of the South-West Front.

* mladi raziskovalec, Zgodovinski inštitut Milka Kosa, ZRC SAZU, Novi trg 2, SI-1000 Ljubljana, gregor.antolicic@zrc-sazu.si 
From the Slovenian perspective this fact matters not only because the Isonzo Front was under this Command, but also because between May 1915 and March 1916 as well as between March 1917 and November 1917 the headquarters of the Command of the South-West Front were located in the Slovenian city of Maribor. Because of the presence of this Command during the Great War, this city by the river Drava attained an exceptional position in comparison with other Slovenian cities. Archduke Eugen and the renowned Svetozar Boroevic von Bojna represent the key protagonists of the organisation and implementation of military actions on the Isonzo battlefield. The core of this article consists of the presentation of the military career of Archduke Eugen, which led him to attain important positions since the beginning of World War I. At the same time the article represents a foundation for the further research of Archduke Eugen's activities during World War I.

Keywords: Archduke Eugen, World War I, Isonzo Front, Command of the South-West Front, Maribor

Kadar govorimo o slovenskem ozemlju v času prve svetovne vojne in njegovi vojaški vpetosti v velike spopade vélike vojne, stopita $\mathrm{v}$ ospredje vloga in pomen Svetozarja Boroevića de Bojne in njemu podrejenih vojakov na soškem bojišču. Toda v času, ko se je Boroević boril ob Soči, je bilo v Mariboru nastanjeno poveljstvo jugozahodne fronte, kateremu je bil podrejen tudi Boroević. To poveljstvo se je nahajalo v Mariboru od 27. maja 1915 do 24. marca 1916 in nato še od 11. marca 1917 do 12. novembra 1917. V tem času je bil poveljnik tega poveljstva nadvojvoda Evgen. Slednji je tako morda ena izmed pozabljenih, vsaj na področju slovenskega zgodovinopisja, vojaških osebnosti prve svetovne vojne. Pričujoči članek vsekakor nima namena osvetliti celotnega pomena življenja in dela nadvojvode Evgena, ampak bodo v njem predstavljeni osnovni biografski podatki v obdobju od leta 1863 do 1915 ter vojaški pomen Evgena od začetka prve svetovne vojne do prvih mesecev po vstopu Kraljevine Italije v vojno. ${ }^{1}$

Nadvojvoda Evgen je bil rojen 21. maja 1863 v mestu Gross-Seelowitz oz. Židlochovice na Moravskem oz. na ozemlju današnje Republike Češke. Njegov oče je bil Karl Ferdinand Avstrijski. Glede na poklicno pot Evgena lahko rečemo, da mu je bila po očetovi strani že v zibelko dana vojaška kariera. Oče Karl Ferdinand je namreč služil v cesarski vojski, med drugim je pomagal pri zatiranju upora 1848 v Pragi in dosegel čin generala. Še vidnejša vojaška osebnost je bil Evgenov ded, oče Karla Ferdinanda, Karl Avstrijski nadvojvoda Tešenski, znameniti zmagovalec nad Napoleonom. Karlu je namreč prvemu uspelo poraziti Napoleona 21. in 22. maja 1809 v bitki pri kraju Aspern. V spomin na vojaške dosežke Karla na dunajskem Heldenplatzu stoji njegov kip, nasproti le-tega pa je kip princa Evgena, po katerem naj bi nadvojvoda Evgen dobil ime. Če se ozremo na drugo stran Evgenove družine,

1 Zoë von Schildenfeld, Erzherzog Eugen 1863-1963 (Innsbruck: Verlag Felizian Rauch, 1963), $62,68,71$. 
je njegova mati Elizabeta Avstrijska izhajala iz madžarske veje Habsburžanov (po pričevanju nadvojvode Evgena naj bi bila njegova mati najprej predvidena za ženo cesarja Franca Jožefa, preden se je ta nesmrtno zaljubil v njegovo Sisi). Njen oče je bil Jožef Anton Habsburški, ki je od leta 1796 zasedal mesto madžarskega palatina. Tako se je v nadvojvodi Evgenu mešala vojaška in politična sposobnost prednikov, ki jo je znal v času svojega življenja zelo dobro izkoristiti. Evgen je imel 6 bratov in sester (od tega sta dva umrla kot dojenčka) in eno polsestro (njegova mati je bila namreč $\mathrm{v}$ prvem zakonu poročena s Ferdinandom Karlom Avstrijskim Este, ki pa je umrl leta 1849). Najbolj znana sestra nadvojvode Evgena je bila Marija Kristina, ki se je 29. novembra leta 1879 poročila s španskim kraljem Alfonsom XII. Tako se še danes v španski kraljevi družini pretaka kri družine nadvojvode Evgena. ${ }^{2}$

\section{Slika 1: Nadvojvoda Evgen von Österreich-Teschen}

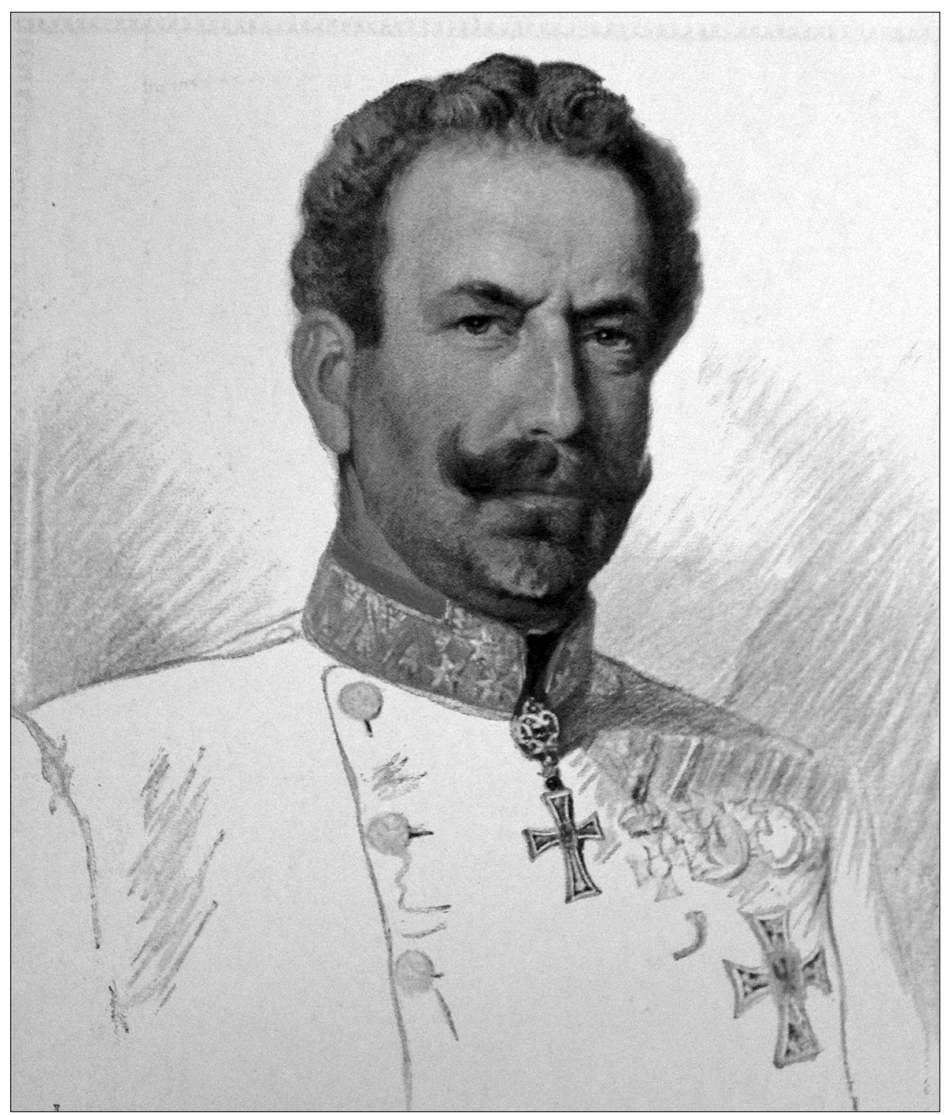

Vir: Pokrajinski arhiv Maribor

2 Schildenfeld, Erzherzog Eugen, 7, 11, 13, 16. Rupert Stummer, Erzherzog Eugen 1863-1954 (Salzburg: Österreichischer Milizverlag, 2009), 28-32. AT-OeStA/HHStA UR FUK 2519, Geburt von Erzherzog Eugen. 
Evgen je svoje otroštvo do leta 1866 preživljal v Brnu, nato pa na Dunaju. Čas počitnic oziroma tako imenovane Sommerfrische (čas, ko sta plemstvo in visoka aristokracija zapustila velika mesta in se odpravila na podeželje) je Evgenova družina preživljala v krajih Gmunden (idilično mestece ob Traunseeju vzhodno od Salzburga in tako tudi v bližini cesarjevega poletnega domicila v Bad Ischlu), Badnu (kraj južno od Dunaja) in Gross-Seelowitzu. Evgena so privatni učitelji poučevali jezike, matematiko, umetnostno zgodovino, glasbo, naravoslovje itd. Kljub navidezno idiličnemu otroštvu je bil Evgen deležen zelo špartanske vzgoje. Ta je predvidevala zgodnje vstajanje, umivanje $s$ hladno vodo ter dolge jutranje sprehode, ki so potekali v vsakem vremenu. Po sprehodu, med katerim tudi ob izredno hladnem vremenu ni bilo dovoljeno dati rok v žep, je sledil zajtrk, ki je bil po navadi sestavljen iz hladnega mleka ter enega kosa suhega črnega kruha. Evgen je kazal tudi veliko glasbeno nadarjenost. Tako sta s sestro Marijo Kristino ob njegovih obiskih v Španiji velikokrat štiriročno igrala na klavir. Enega izmed teh obiskov se je Evgen spominjal takole: "Nekega dne je ponovno prišlo do nemirov in hrup s ceste je bilo slišati tudi v palači. Da bi pomirila kraljičino tašco, ki je bila že nekoliko starejša gospa, sva s kraljico zaigrala štiriročno na klavir in to tako glasno, da v sobi ni bilo več slišati hrupa s ceste. ${ }^{3} \mathrm{Ob}$ običajni aristokratski vzgoji je bil Evgen tako kot večina mladih nadvojvod avstrijske dedne hiše v zgodnjem otroštvu deležen tudi vojaške vzgoje. ${ }^{4}$

Leta 1874, ko je bilo Evgenu 11 let, mu je umrl oče. ${ }^{5}$ Za skrbnika Evgena in njegovih mladoletnih bratov in sester je bil imenovan brat očeta, nadvojvoda Albrecht. ${ }^{6}$ Slednji je v času svojega življenja zgradil vojaško kariero, dosegel čin feldmaršala, zasedel položaj generalnega inšpektorja avstro-ogrske vojske in bil tesni sodelavec Franca Jožefa. Nadvojvoda Albrecht je vsekakor močno vplival na Evgenovo nadaljnjo vojaško pot. Že v letu 1877, natančneje 27. oktobra, pa se je za šele 14-letnega Evgena pričela vojaška kariera. Takrat je bil namreč imenovan za poročnika tirolskega strelskega polka cesar Franc Jožef (Tiroler Jäger-Regiment Kaiser Franz Josef). Vojaško pot je nadaljeval v letu 1878 pri 24. lovskem bataljonu v Hainburgu (zahodno od Bratislave), leta 1879 pri 73. pehotnem polku v Egerju (Madžarska) in leta 1880 pri 8. dragonskem polku v Moosbrunnu pri Dunaju. 24. aprila 1881 je bil nadvojvoda Evgen povišan v nadporočnika in hkrati premeščen iz tirolskega strelskega polka $\mathrm{k} 2$. huzarskemu polku. 13. septembra 1884 je bil premeščen v 5. huzarski polk. Med leti 1882 do 1884 je Evgen obiskoval cesarsko kraljevo vojaško šolo na Dunaju, ki jo je uspešno zaključil s tem, ko je opravil končni izpit 1 . novembra leta 1885 . Za vstop na vojaško šolo je moral opraviti sprejemni izpit pred komisijo, ki jo je imenoval njegov stric in skrbnik nadvojvoda Albrecht. Evgen je tako postal do tedaj edini nadvojvoda, ki je opravil večletno šolanje na vojaški šoli. ${ }^{7}$ Med njegovimi vrstniki na vojaški šoli

3 Schildenfeld, Erzherzog Eugen, 13.

4 Ibid., 7, 12-13, 15. Stummer, Erzherzog Eugen, 32-37.

5 „Erzherzog Karl Ferdinand, « Prager Abendblatt, 21. 11. 1874, 1. Schildenfeld, Erzherzog Eugen, 11. Stummer, Erzherzog Eugen, 29.

6 AT-OeSta/HHStA UR FUK 2626, Adoptions-Urkunde. Stummer, Erzherzog Eugen, 36.

7 Schildenfeld, Erzherzog Eugen, 7, 11. Stummer, Erzherzog Eugen, 55-59, 64, 87-103. 
je bil tudi Štefan Sarkotić von Lovčen. Slednji je bil po odhodu Oskarja Potioreka 1. januarja 1915 imenovan za poveljujočega generala in guvernerja Bosne in Hercegovine. ${ }^{8}$ Do naslednje premestitve nadvojvode Evgena je nato prišlo 24. oktobra 1885, ko je bil imenovan za stotnika pri 5 . huzarskem polku. Naslednjo stopnjo v vojaški hierarhiji je dosegel 25 . oktobra $1888 \mathrm{z}$ imenovanjem za majorja ter premestitvijo iz 5. huzarskega polka k 100. pehotnemu polku v Olomucu. Po dobrem letu delovanja $\mathrm{v}$ činu majorja je bil 1. novembra 1889 imenovan za podpolkovnika. 1. maja 1890 je bil nato imenovan za polkovnika in poveljnika 100. pehotnega polka. 14. oktobra 1891 je bil kot poveljnik premeščen k 13. huzarskemu polku v Budimpešto. 17. oktobra 1893 je postal poveljnik 9. pehotne brigade v Olomucu. Le nekaj dni kasneje, natančneje 28. oktobra 1893 , je bil povišan v čin generalmajorja. ${ }^{9}$

Leta 1894 je Evgen postal 58. Hochmeister nemškega viteškega reda. ${ }^{10} \mathrm{~S}$ to funkcijo se je zavezal k celibatu, kar je verjetno glavni razlog, da ni imel potomcev. $\mathrm{Na}$ mestu Hochmeistra je ostal do leta 1923, ko je na lastno željo odstopil s tega položaja. Hkrati je bil nadvojvoda Evgen zadnji posvetni Hochmeister. Ta naslov in lastništvo nad 4. pehotnim polkom je Evgen podedoval po smrti nadvojvode Wilhelma. 8. februarja 1896 je cesar Franc Jožef nadvojvodo Evgena imenoval za poveljnika 25. pehotne divizije na Dunaju. Predhodna poveljnika te divizije sta bila nadvojvoda Johann Salvator (znani Enfant terrible habsburške družine, ki je na lastno željo leta 1889 izstopil iz družine in se od tedaj imenoval Johann Orth) in prestolonaslednik Rudolf. Tako je Evgen, tedaj star 33 let, za nekaj časa ponovno prispel na Dunaj. V tem času je kot Hochmeister nemškega viteškega reda stanoval v rezidenci na dunajskem Parkringu, imenovani tudi Palais Wilhelm oz. Deutschmeister Palais. Mlad, bogat, pameten, glasbeno nadarjen in postaven Evgen je $\mathrm{v}$ tem času buril duhove marsikatere dunajske fine dame. Vendar je bil, kot smo že omenili, kot Hochmeister nemškega viteškega redu zavezan celibatu. Po štirih letih je 3. aprila 1900 z imenovanjem za poveljnika 14. korpusa in komandirnega generala v Innsbrucku ter deželno-obrambnega poveljnika Tirolske in Vorarlberga zapustil Dunaj. 27. aprila 1901 je bil imenovan za generala konjeništva. V času bivanja na Tirolskem se je Evgen v imenu cesarja večkrat udeležil različnih političnih in vojaških prireditev. Leta 1908 ga je cesar imenoval za glavnega vojaškega poveljnika tirolske in vorarlberške deželne obrambe in generalnega vojaškega inšpicienta (Generaltruppeninspektor). ${ }^{11}$

Po mnogih letih služenja vojske je nadvojvodi Evgenu cesar 29. junija 1912 odobril enoletni dopust, za katerega je Evgen zaprosil iz zdravstvenih razlogov. Razlag, zakaj se je odločil za ta korak, je več. Conrad von Hötzendorf v svojih spominih na-

8 O. F. Winter, "Sarkotić von Lovčen, «v: Österreichisches Biographisches Lexikon, Band 9 (Wien: Verlag der Österreichischen Akademie der Wissenschaften, 1988), 424-25.

9 Schildenfeld, Erzherzog Eugen, 7, 11, 58-60. Stummer, Erzherzog Eugen, 55-59, 64, 87-103.

10 "Die Hochmeister«, Deutscher Orden, Brüder und Schwestern vom Deustchen Haus St. Mariens in Jerusalem, pridobljeno 28. 8. 2015, http://www.deutscher-orden.at/site/geschichte/hochmeister.

11 Stummer, Erzherzog Eugen, 47-54, 106, 118, 121-124, 179-185. "Inthronisation des Hochund Deutchmeisters Erzherzog Eugen, Mä̈hrisches Tagblatt, 20. 11.1894, 3-4. Schildenfeld, Erzherzog Eugen, 7, 29-32, 58-60. »Amtlicher Teil«, Worarlberger Landes-Zeitung, 3. 12. 1894, 1. 
kaže dejstvo, da je vedno bolj priljubljeni Evgen vzbujal ljubosumje pri prestolonasledniku Francu Ferdinandu in se je zaradi tega moral umakniti iz aktivnega vojaškega služenja. Vendar avtor Rupert Stummer v svoji knjigi Erzherzog Eugen objavlja pisma iz zapuščine Franca Ferdinanda. Slednja sta si Evgen in prestolonaslednik pošiljala v letu 1912. V njih se je Evgen pritoževal nad slabim zdravstvenim stanjem. Tožil je o krčnih žilah v nogah, ki so mu onemogočile daljše jahanje, hojo in dolgotrajno stanje. Tako so razlogi za začasni Evgenov umik iz aktivnega služenja avstro-ogrski vojski po Stummerjevem mnenju nekje vmes med zdravstvenimi težavami in nelagodjem Franca Ferdinanda zaradi vedno večje priljubljenosti nadvojvode Evgena. ${ }^{12}$

Na tem mestu velja omeniti tudi, kakšen je bil odnos med nadvojvodo Evgenom in prestolonaslednikom Francem Ferdinandom do leta 1912. Prva skupna točka je bila enaka starost, oba sta bila namreč rojena 1863 . Druga skupna točka je bila vsekakor ljubezen oziroma strast do vojske. $\mathrm{V}$ dolgih pismih, ki sta si jih pisala med leti 1878 in 1885, sta izmenjala veliko misli o različnih rodovih avstro-ogrske vojske ter prišla do skupnega zaključka, da po njunem mnenju konjenica predstavlja najboljše orožje vojske. Hkrati pa sta tudi venomer poudarjala, da je vojska v monarhiji edino zagotovilo obstojnosti. V letu 1896 je Franc Ferdinand zbolel na pljučih. Nekateri dunajski krogi so ga zaradi tega že odpisali in za bodočega prestolonaslednika imeli njegovega mlajšega brata Otta. Toda čeprav je med cesarjem in Francem Ferdinandom obstajala antipatija, je bil Franc Jožef prepričan, da je Otto kot bodoči prestolonaslednik in cesar še slabša izbira. Tako je cesar, da bi dokazal, da kljub slabemu zdravstvenemu stanju še vedno računa nanj, 26. aprila 1896 Franca Ferdinanda imenoval za feldmaršalskega polkovnika. V tem času je Evgen Francu Ferdinandu napisal pismo, v katerem ga je pozival, naj počiva, da bo čim hitreje ozdravel. Toda zdravstveno stanje Franca Ferdinanda se kljub počitku ni izboljšalo, zaradi česar so zdravniki predlagali spremembo klime. Zato se je Franc Ferdinand odpravil na daljše zdravljenje v Egipt. V času zdravljenja ga je tam obiskal tudi nadvojvoda Evgen. Ob koncu tega obiska je Evgen Francu Ferdinandu obljubil, da bo cesarju poročal o izboljšanju njegovega zdravstvenega stanja. Kljub očitnim nesoglasjem oziroma ljubosumju prestolonaslednika, ki je vplivalo na začasni Evgenov umik iz vojaškega služenja, je med njima vladalo prijateljstvo in medsebojno zaupanje ter spoštovanje. $\mathrm{Na}$ to kaže tudi dejstvo, da se je prestolonaslednik, preden je za vodjo svoje vojaške pisarne februarja 1906 imenoval Aleksandra Broscha von Aarenaua, posvetoval tudi z nadvojvodo Evgenom. ${ }^{13}$

Po usodnem atentatu v Sarajevu in izbruhu prve svetovne vojne je Evgen v letu 1914 ponovno vstopil v aktivno služenje avstro-ogrske vojske. Od začetka vojne je avstro-ogrski vojski na balkanskem bojišču poveljeval nekdanji guverner Bosne in Hercegovine Oskar Potiorek. Vendar njegovo vodenje za monarhijo izredno po-

12 Stummer, Erzherzog Eugen, 121-24.

13 Gerd Holler, Franz Ferdinand von Österreich-Este (Wien: Verlag Carl Ueberreuter, 1982), 77, 80, 137, 153. Wladimir Aichelburg, Erzherzog Franz Ferdinand von Österreich-Este 1863-1914, Band 1 1858-1899 (Wien: Verlag Berger, 2014), 799-800. 
membnega bojišča ni bilo uspešno. Prvi velik poraz proti Srbom so Avstrijci doživeli v bitki na Ceru, ki je trajala od 16. do 24. avgusta 1914. Že 12. avgusta je avstro-ogrska 5. armada prestopila mejne reke in zasedla kraj Šabac ob južnem nabrežju Save. Za Avstrijce je bil to v danem trenutku seveda velik uspeh. Toda v glavnini bitke je Srbom uspelo premagati Avstrijce, ki so bili prisiljeni v umik. V naslednji bitki pri reki Drini, ki je trajala od 6. septembra do 4. oktobra 1914, je Potioreku uspelo doseči neodločen izid. Pri tem pa je treba poudariti, da je pred to bitko prišlo do premestitve avstro-ogrske 2. armade v Galicijo, kar je zagotovo oslabilo položaj Avstrijcev na Balkanu. Zadnji spopad pod vodstvom Potioreka je bila bitka na Kolubari, ki je trajala od 16. novembra do 15 . decembra 1914 . V njej je bila avstrijska vojska že drugič poražena. Srbska zmaga nad avstro-ogrsko vojsko je presenetila celo nemškega cesarja Wilhelma II., ki je osebno čestital vojnemu nasprotniku Radomiru Putniku, načelniku glavnega generalštaba srbske vojske. ${ }^{14}$

Porazi na balkanskem bojišču so Potioreka prisilili k predčasni upokojitvi. Zaradi vojaških neuspehov je bil Potiorek deležen tudi diskreditacije svojega dotedanjega dela. Tako je eden izmed avstrijskih poslancev glede Potioreka dejal: »Potiorek, ki je bil svoj čas guverner v Bosni, sam ni videl kako tam izgleda... Njegov prvi zločin je bil, da je v popolni nevednosti tamkajšnje situacije žrtvoval prestolonaslednika Franca Ferdinanda ... Tega moža so nato postavili za poveljnika proti Srbiji ... Če ni normalen, spada na psihiatrijo. Č je normalen potem sodi na vislice za vse vojake, ki so bili zaradi njega žrtvovani. "15 Franc Jožef je tako dotedanjega poveljnika balkanskih sil odstavil, oz. bolje, ga upokojil, in na njegovo mesto 22. decembra 1914 imenoval nadvojvodo Evgena. V časniku Štajerc so na to temo zapisali: "Glavni poveljnik naših $v$ Srbiji nastopajočih vojakov, feldcajgmojster Potiorek šel je iz zdravstvenih ozirov v pokoj. Glavno komando na jugu prevzel je zdaj nadvojvoda Evgen, general kavaljerije, katerega sliko danes prinašamo. "16 Očitno v danem trenutku Evgenove zdravstvene težave niso bile več bistvene, saj ga je delo poveljnika strateško izredno pomembnega bojišča telesno zelo obremenjevalo. Sedež poveljstva je bil v mestu Petrovaradin, pri katerem je leta 1716 princ Evgen dosegel pomembno zmago nad Turki. Prve ukaze kot poveljnik balkanskih sil je Evgen s strani vrhovnega vojaškega poveljstva (Armeeoberkommando - AOK) prejel 23. decembra. V njih so bile začrtane prednostne naloge novega poveljnika. Temeljna oziroma "minimalna« naloga je bila preprečiti srbski vojski vdore v monarhijo, predvsem tiste, ki bi šli v smeri Dunaja in Budimpešte. Tako je postala najpomembnejša naloga nadvojvode Evgena, da sebi podrejeno vojsko usposobi tako, da bo zmožna nasprotnikove napade uspešno odbiti. Poseben položaj pri obrambi balkanskega bojišča bi po mnenju AOK moralo zavzeti tudi Sarajevo. Vendar je bil strah AOK in Conrada von Hötzendorfa, da bi srbska vojska

14 Edmund Glaise-Horstenau et al., Österreich-Ungarns Letzter Krieg 1914-1918, Band I (Wien: Verlag der Militärwissenschaftlichen Mitteilungen, 1931), 110-54, 603-43, 679-764. Hptm. Mag. Alois Tigelhadt, "Die Schlacht an der Kolubara, "Zeitschrift der Offiziersgesellschaft Steiermark, 4/14 (2014): 14-15.

15 Ibid.

16 "Nadvojvoda Evgen«, Štajerc, 10. 1. 1915, 5. 
izvedla protiofenzivo, neutemeljen. Srbi so namreč v kolubarski bitki utrpeli velike izgube, ki so onemogočile nadaljnje ofenzivne operacije. Ob temeljni nalogi odbijanja morebitnih srbskih napadov je AOK opozoril Evgena, da zaradi dogajanja na "glavnem bojičču", se pravi na vzhodni fronti, v prihodnje ni bilo mogoče računati na povečanje števila vojakov na Balkanu. Dejansko pa se je zgodilo nasprotno. $\mathrm{Ne}$ samo da nove okrepitve niso bile mogoče, celo obstoječe vojake so premestili na vzhodno bojišče, kjer je od decembra 1914 do marca 1915 potekala zimska ofenziva v Karpatih. Tako je bil z Balkana 10. januarja 1915 odpoklican XIX. korpus, temu pa je 20. januarja sledil še XIII. korpus. Kljub slabitvi avstrijskega položaja na Balkanu se je Evgen dobro zavedal, kakšnega pomena je bila zimska ofenziva proti Rusom. Zaradi tega je vrhovnemu vojaškemu poveljniku nadvojvodi Friedrichu (slednji je bil starejši brat nadvojvode Evgena) sam predlagal, da se na vzhodno bojišče premesti še VIII. korpus. Tega so nato premestili na vzhodno bojišče 3. februarja 1915. Evgenu sta tako na Balkanu za zavrnitev možnega srbskega napada, ki pa ga ni bilo pričakovati, ostala le XV. in XVI. korpus. Tako sta slabitev srbske vojske po kolubarski bitki in odhod avstro-ogrskih moštev na vzhodno bojišče povzročili, da v času Evgenovega vodenja poveljstva balkanskih sil ni prišlo do večjih ozemeljskih sprememb. Hkrati pa zaradi omenjenega premika čet tudi ni prišlo do uresničitve Conradove želje po januarski ofenzivi proti Srbiji. S slednjo so zaradi pritiskov Nemčije namreč želeli omogočiti vojaško oskrbo Turčije po reki Donavi. ${ }^{17}$

Relativno kratek čas po Evgenovem imenovanju na čelo poveljstva balkanskih sil je v vojno na strani antante 23. maja 1915 vstopila Kraljevina Italija. Zaradi tega je bil Evgen 24. maja 1915 imenovan za poveljnika novonastalega poveljstva jugozahodne fronte. Tri dni kasneje, se pravi 26. maja, je bilo poveljstvo iz Petrovaradina premeščeno v Maribor, kamor je nadvojvoda Evgen prispel 27. maja. Poveljstvo je bilo nameščeno v Scherbaumovi vili v današnji ulici Heroja Tomšiča 5. V tej stavbi se danes nahaja Muzej narodne osvoboditve Maribor. Tako je Maribor sredi vojne vihre postal pomembno središče v poveljniški strukturi avstro-ogrske vojske. Le dan pred vojno napovedjo Italije je cesar Franc Jožef nadvojvodo Evgena imenoval za generala polkovnika. O tem so nekaj dni kasneje poročali tudi v časniku Slovenec: "Ljubi gospod nečak, nadvojvoda Evgen. Ustanovil sem šaržo generala polkovnika in me veseli, da Vas prvega povišam v to šaržo. Franc Jožef «. ${ }^{18}$ Slovenski javnosti je bil Evgen nekoliko obširneje predstavljen v časniku Slovenec nekaj dni kasneje: "Imenovanje nadvojvode Evgena na odgovorno mesto najvišjega poveljnika armadi, ki nastopi proti Italiji, pozdravlja vsa javnost in osobito vojaški krogi, ki so navdušeni za nadvojvodo vsled njegovih visokih sposobnosti in njegovega človekoljublja. "19 Nadalje so v članku opozarjali na dober odnos med Evgenom in ubitim prestolonaslednikom Francem Ferdinandom, češ «da je že rajni prestolonaslednik nadvojvoda Franc Ferdinand ob

17 Schildenfeld, Erzherzog Eugen, 60-62. Stummer, Erzherzog Eugen, 124-127. AT-OeSta/KA NL

B1139, Depeša AOK nadvojvodi Evgenu 23. 12. 1914, Nachlass Erzherzog Eugen.

18 „Nadvojvoda Evgen imenovan za generalnega polkovnika,« Slovenec, 27. 5. 1915, 4.

19 „Nadvojvoda Evgen,«Slovenec, 31. 5. 1915, 1. 
vsaki priliki v polni meri priznaval strategične sposobnosti nadvojvode Evgena in ga smatral kot najboljšega in najodličnejšega naših generalov. « ${ }^{20}$ Nadvojvoda Evgen je po vstopu Kraljevine Italije v vojno postal vrhovni poveljnik 600 kilometrov dolge frontne črte, ki se je raztezala od meje s Švico pa vse do obale Jadranskega morja. Zaradi vojskovanja Avstro-Ogrske na več frontah je bil položaj na novem bojišču izredno slab. Za obrambo dolge frontne linije je tako bilo na voljo zgolj okoli 100.000 avstro-ogrskih vojakov, ti pa so se morali upreti približno osemkrat močnejši italijanski vojski. ${ }^{21}$

V času prve nastanitve poveljstva jugozahodne fronte v Mariboru od maja 1915 do marca 1916 je na bojišču ob Soči potekalo prvih pet soških bitk. Nadvojvoda Evgen se je dobro zavedal težkega položaja vojakov na jugozahodnem bojišču. Tako se je zaradi visokega krvnega davka, ki ga je terjala druga soška bitka, 29. julija 1915 odpravil sam v Ljubljano na pogovore z Boroevićem. Od Boroevića je zahteval gradnjo globljih jarkov, ki bi vojakom v primerjavi s kamnitimi nasipi omogočili boljšo zaščito pred italijansko artilerijo. Toda Boroević ja zagovarjal mnenje, da drugačne zaščite, kot je bila obstoječa, zaradi kamnite podlage kraških tal ni bilo mogoče izvesti. Načelnik štaba poveljstva jugozahodne fronte feldmaršal Alfred Kraus, ki je na sestanku spremljal nadvojvodo Evgena, je kljub temu zahteval izgradnjo obrabnih jarkov s pomočjo miniranja. ${ }^{22}$ Sredi trajanja tretje soške bitke (18. oktober do 4. november 1915) se je nadvojvoda Evgen 22. in 23. oktobra odpravil na obisk fronte, da bi se lahko sam prepričal, kakšno je stanje na fronti. Ob tem obisku je Evgen izrazil prepričanje, da bo kljub močnemu italijanskemu napadu frontna črta zdržala nasprotnikov pritisk. $^{23}$

Kljub temu da je Boroeviću z ukazi na soški fronti in nadvojvodi Evgenu s poveljevanjem celotnemu jugozahodnemu bojišču uspelo v prvem letu po vstopu Kraljevine Italije v vojno doseči pomemben cilj in v veliki meri preprečiti vdor Italijanov na ozemlje monarhije, med obema poveljnikoma ni vladalo prijateljsko vzdušje. Boroević je tako že po drugi soški bitki pri cesarju in AOK vložil prošnjo za upokojitev. V njej je zapisal, da se nikakor ne more strinjati z ukazi, ki jih je prejemal s strani poveljstva jugozahodne fronte. Hkrati je poudarjal, da monarhija stoji na dveh stebrih, in sicer dinastiji in vojski, zaradi česar je bil mnenja, da je izrednega pomena, da se ugled dinastije in vojske ohrani tudi v času vojskovanja. Toda po mnenju Boroevića nadvojvoda Evgen ni sledil takšnim ciljem, kar pa je pri Boroeviću vzbudilo željo

20 Ibid.

21 „Vojska z verolomno Italijo, « Slovenski gospodar, 27. 5. 1915, 1. Schildenfeld, Erzherzog Eugen, 62. Stummer, Erzherzog Eugen, 127. Walter Lukan, Iz »črnožolte kletke narodov« $v$ "zlato svobodo«?: Habsburška monarhija in Slovenci v prvi svetovni vojni (Ljubljana: Znanstvena založba Filozofske fakulteta Univerze v Ljubljani, 2014), 38. Miro Simčič, Die Schlachten am Isonzo. 888 Tage Krieg im Karst in Fotos, Karten und Berichten (Graz: Leopold Stocker Verlag, 2003), 27. Edmund Glaise-Horstenau et al., Österreich-Ungarns Letzter Krieg 1914-1918, Band II. (Wien: Verlag der Militärwissenschaftlichen Mitteilungen, 1931), 412.

22 Johannes Held, "Erzherzog Eugen von Österreich. Soldat-Ordensritter-Mäzen« (doktorska disertacija, Universität Wien, 2010), 126.

23 Schildenfeld, Erzherzog Eugen, 64. 
Slika 2: Nadvojvoda Evgen (spredaj v sredini) kot poveljnik jugozahodne fronte pred Scherbaumovo vilo v Mariboru (spredaj levo general Karl von Bellmond, spredaj desno avstro-ogrski vojni minister Alexander von Krobatin)

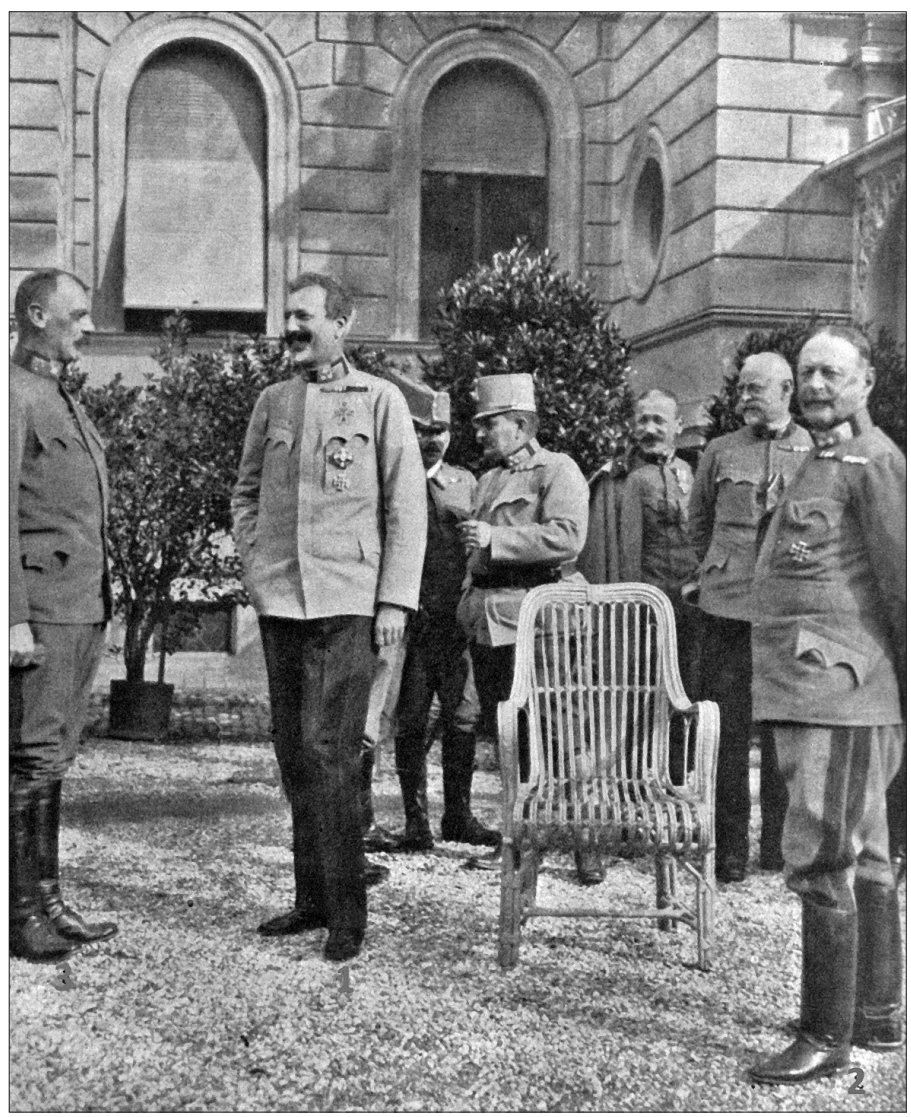

Vir: Karnisch-Julische Kriegszeitung, 22. 4. 1916, 13

po upokojitvi. Slednjo je najprej vložil pri poveljstvu jugozahodne fronte, ker pa so mu jo tam zavrnili, se je obrnil naravnost na cesarja. Ob lepih besedah iz uradne prošnje za upokojitev naj bi Boroevićevi razlogi za takšno odločitev bili drugje. V pismu dolgotrajnemu prijatelju Franzu von Volgarju, ki je bilo objavljeno v časniku Jutro v začetku februarja 1929, je Boroević 20. avgusta 1915 zapisal, da mora najprej razčistiti nastalo situacijo na fronti. Nadalje je zapisal: „Včeraj sem vložil prošnjo za upokojitev... Ne sme več tako iti naprej, moram stvar spraviti v red. Prišel sem namreč na to, da vohunijo proti meni... neki zaupnik nadvojvode Evgena je poslal mlade oficirje na fronto in jim dal poseben ključ za šifriranje, ki je bil nam neznan. Takšen šifrirani telegram mi je bil predložen. ${ }^{24}$ Toda šifrirani telegram naj bi sodelavci Boroevića hitro razvozlali. Tako je Boroević izvedel, da na poveljstvu preučujejo možnosti, kako

24 »Maršal Boroević v svojih pismih, « Jutro, 1. 2. 1929, 6. 
bi se ga znebili. Kot ena izmed možnosti je bila navedena tudi upokojitev. Zato se je odločil, da nadrejene prehiti. Toda njegova želja ni bila uslišana. ${ }^{25}$

$\mathrm{V}$ časniku Jutro so nadalje tudi poročali, da ni bila izključena možnost, da so pri delovanju proti Boroeviću nadvojvodi Evgenu pomagali tudi mariborski "nemškutarji«, ${ }^{26}$ s katerimi naj bi imel Evgen tesne stike. Po mnenju slednjih Boroeviću ni bilo zaupati, ker je bil Srb. Naslednje pismo je Boroević poslal Volgarju 9. septembra 1915 in v njem zapisal: "Mojo prvo prošnjo so odbili in mi še očitajo da sem se prenaglil... Prepis vse korespondence sem poslal Conradu (sef generalnega štaba) v Tešin, da s tem preprečim da bi bili tamkaj enostransko informirani. Conrad mi je odgovoril, da mora on še več požreti, da je on še na slabšem ... Ukaz je bil izdan v Maribor, naj se ne vmeśavajo v moje stvari. Za ukaz se seveda nihče ne briga in vse je ostalo pri starem. Vsak dan si govorim: Nam ni pomoči, samo eno sredstvo je, ki labko pomaga, in to je: od armadnega vodstva je treba odstraniti vse, ki nimajo pojma o vojevanju. «27 Toda kljub ukazu AOK poveljstvu jugozahodne fronte naj bi se delovanje proti Boroeviću nadaljevalo oz. celo stopnjevalo. Boroević je zaradi tega celo razmišljal, da bi javno povedal, kakšno je stanje znotraj poveljstva. V pismu, datiranem 25. oktobra 1915 , je tako zapisal: "Zares vedno bolj se približujem trenutku ko bom primoran zateči se $v$ javnost, da pomandram gotove spletke. Znaki kažejo na to, da v Tešinu verujejo, da sem $v$ zvezi z dunajsko vojaško pisarno, ki me baje protežira. Niti besedice na tem ni res. Tako neumen nisem, da bi hodil v takšno past. Značilna pa je stvar za harmonijo o najvišjih sferah in za položaj, ki sem si ga ustvaril po 45 letih. "28 Iz citiranega pisma lahko razberemo, da je Boroević očitno izgubil tudi zaupanje do AOK.

$\mathrm{Ob}$ uspešnem vodenju poveljstva in velikem razumevanju nadvojvode Evgena za potrebe in tegobe vojakov je imel slednji nekoliko drugačne poglede na politično situacijo na ozemlju pod okriljem poveljstva jugozahodne fronte. Po vstopu Kraljevine Italije v vojno je namreč avstrijski ministrski predsednik Karel Stürgkh želel spodbuditi vojskovalni duh Slovencev in Hrvatov. Zato se je zavzemal za amnestijo političnih zločinov, zagrešenih od začetka vojne naprej v južnoslovanskih predelih Cislajtanije. Stürgkh je namreč vojnega ministra Alexandra Krobatina že v novembru 1914 opozarjal na številna preganjanja in zapiranja na slovenskem in hrvaškem ozemlju. Po vstopu Kraljevine Italije v vojno je Stürgkh 31. maja 1915 Krobatinu poslal predlog za amnestijo in razveljavitev zapornih kazni za politične prekrške oseb južnoslovanskih narodnosti na območju Dalmacije, Primorske, Kranjske, Koroške in Štajerske. Krobatin se je nato posvetoval z AOK in s poveljstvom jugozahodne fronte, ki pa sta sprejetju amnestije odločno nasprotovala. V noti, ki jo je poveljstvo pod vodstvom nadvojvode Evgena poslalo Krobatinu, je bilo zapisano, da je slovensko podeželsko

25 Stummer, Erzherzog Eugen, 131. Dušan Nećak in Božo Repe, O Feldmaršalu Svetozarju Boroeviću de Bojni (Ljubljana: Filozofska fakulteta Univerze v Ljubljani, 2010), 21-22. »Maršal Boroević v svojih pismih,"Jutro, 1. 2. 1929, 6.

26 "Maršal Boroević v svojih pismih", 6. "Sveta življenje in vrvenje. Boroević, Cadorna in Tešin," Slovenec, 31. 1. 1929, 6.

27 Ibid.

28 Ibid. 
prebivalstvo bilo nedvomno lojalno monarhiji in se je zaradi tega tudi v vojni proti Srbom izkazalo za zanesljivo, vendar pa je bila slovenska inteligenca, na čelu z nekdanjim ljubljanskim županom Hribarjem, proti monarhiji sovražno naravnana. ${ }^{29}$ Negativna nastrojenost poveljstva jugozahodne fronte do slovenske inteligence se kaže tudi v poročilu dr. Albina Schagerja o političnih ciljih slovenske inteligence (Die politischen Ziele der slowenischen Intelligenz), ki ga je slednji pripravil marca 1916 za poveljstvo jugozahodne fronte. Tudi v tem spisu pisec zastopa mnenje, da je glavnina slovenskega prebivalstva zvesta monarhiji, le inteligenca predstavlja težave. Po pisanju Schagerja je ni dobro odnesel niti Ivan Šusteršič, ki je bil sicer vse do konca zvest monarhiji, saj je po mnenju Schagerja Šusteršič pri svojem političnem nastopanju v zadevah jugoslovanskega vprašanja zastopal nazore, ki so bili v nasprotju z avstrijskimi stališči. Kot neoporečno je bilo označeno le delovanje Ivana Tavčarja na položaju ljubljanskega župana, čeprav je bilo v spisu hkrati kritizirano, da Tavčarjeva žena ob izbruhu vojne ni odložila reda sv. Save 4. stopnje, ki ga je prejela od srbskega kralja Petra leta $1910 .{ }^{30}$ Toda kljub negativni usmeritvi poveljstva jugozahodne fronte do slovenske inteligence tega vsekakor ne smemo enačiti $\mathrm{z}$ anti-slovensko usmeritvijo poveljstva. Mnogi obiski nadvojvode Evgena na fronti in v zaledju ter zavzemanje za tegobe vojakov, med katerimi je bilo tudi mnogo Slovencev, vendarle kažejo na drugo plat osebnosti nadvojvode Evgena. Vsekakor pa delovanje proti slovenski inteligenci meče senco na dobro vojaško vodenje poveljstva jugozahodne fronte. ${ }^{31}$

$\mathrm{V}$ času prvega bivanja nadvojvode Evgena v Mariboru sta se v mestu zvrstila dva visoka obiska. Najprej je v Maribor 23. januarja 1916 prispel takratni dunajski župan Richard Weiskirchen, ki je Dunaju poveljeval od januarja 1913 do maja 1919. O tem so poročali tudi v časniku Slovenec, kjer so zapisali: "Dunajski župan na laški bojni črti. Na vabilo generalnega polkovnika nadvojvode Evgena je odpotoval dunajski župan dr. Weiskirchner na laško bojišče, da obǐšce dunajske čete. «32 Istega dne so v Slovencu poročali tudi o tem, da je imelo zagrebško vseučilišče 1. februarja 1916 namen podeliti doktorski diplomi nadvojvodi Evgenu in generalu Svetozarju Boroeviću. ${ }^{33}$ Naslednjega visokega obiska je bil Maribor deležen 15. marca 1916, ko se je na poveljstvu jugozahodne fronte oglasil prestolonaslednik Karl Franc Jožef, ki je prevzel vodstvo nad XX. korpusom. ${ }^{34}$ Obisk prestolonaslednika je potekal le dan pred koncem pete soške bitke, ki je trajala od 11. do 16. marca 1916. Kot njene predhodnice je bila tudi ta za italijansko stran neuspešna. Nadvojvoda Evgen je nato 24. marca 1916 zapustil Maribor in poveljstvo jugozahodne fronte. Zatem je bil imenovan za poveljnika Heeresgruppe Tirol. To poveljstvo je imelo sedež v mestu Bozen, ki leži

29 Lukan, Iz "črnožolte kletke narodov«, 40-41.

30 Rok Stergar, »'Politični cilji slovenske inteligence': Nekaj o vohunih in vojakih, «Zgodovina za vse 5, št. 1 (1998): 21-29.

31 Stummer, Erzherzog Eugen, 138, 142. Ernst Wurmbrand, Ein Leben für alt-Österreich, ur. Lorenz Mikoletzky (Wien: Verlag Carl Ueberreuter, 1988), 373-80.

32 "Dunajski župan na laški bojni črti, «Slovenec, 25. 1.1916, 4.

33 „Doktorski diplomi, «Slovenec, 25. 1. 1916, 5.

34 "Dnevne novice, «Slovenec, 18. 3. 1916, 5. 
v današnji Italiji in je glavno mesto Južne Tirolske. 11. marca 1917 je nadvojvoda Evgen ponovno postal poveljnik jugozahodne fronte s sedežem v Mariboru. Sedež poveljstva so nato 12. novembra 1917 prestavili v Videm. Po pogovorih, ki sta jih imela nadvojvoda Evgen in cesar Karel I. v Vidmu 20. decembra 1917, je bilo poveljstvo jugozahodne fronte 11. januarja 1918 razpuščeno. Tako je nadvojvoda Evgen v 55. letu starosti končal svojo aktivno vojaško kariero. Po koncu vojne je od leta 1919 do 1934 živel v Švici. Za tem se je 23. maja 1934 predvsem zaradi svojega velika ugleda lahko vrnil v Avstrijo. Umrl je 30. decembra 1954 v mestu Meran, star 91 let. ${ }^{35}$

\section{Viri in literatura}

Arhivski viri:

- Österreichisches Staatsarchiv, Haus-, Hof und Staatsarchiv (AT-OeStA/HHStA):

- Adoptions-Urkunde (UR FUK) 2626.

o Geburt von Erzherzog Eugen (UR FUK) 2519.

- Österreichisches Staatsarchiv, Kriegsarchiv (AT-OeSta/KA): o (NL) B1139.

Časopisni viri:

- "Amtlicher Teil.» Worarlberger Landes-Zeitung, 3. 12.1894.

- „Dnevne novice."Slovenec, 18. 3. 1916.

- „Doktorski diplomi.«Slovenec, 25. 1. 1916.

- "Dunajski župan na laški bojni črti.« Slovenec, 25. 1. 1916.

- „Erzherzog Karl Ferdinand." Prager Abendblatt, 21. 11. 1874.

- "Inthronisation des Hoch- und Deutchmeisters Erzherzog Eugen."Mährisches Tagblatt, 20. 11. 1894.

- "Maršal Boroević v svojih pismih."Jutro, 1. 2. 1929.

- "Nadvojvoda Evgen imenovan za generalnega polkovnika.«Slovenec, 27. 5. 1915.

- "Nadvojvoda Evgen.«Slovenec, 31. 5. 1915.

- „Nadvojvoda Evgen.«Štajerc, 10. 1. 1915.

- "Sveta življenje in vrvenje. Boroević, Cadorna in Tešin."Slovenec, 31. 1.1929.

- „Vojska z verolomno Italijo.« Slovenski gospodar, 27. 5. 1915.

Internetni viri:

- Deutscher Orden, Brüder und Schwestern vom Deustchen Haus St. Mariens in Jerusalem. „Die Hochmeister«. Pridobljeno 28. 8. 2015. http://www.deutscher-orden.at/site/geschichte/hochmeister.

Literatura:

- Aichelburg, Wladimir. Erzherzog Franz Ferdinand von Österreich-Este 1863-1914. Zv. 1, 1858 1899. Wien: Verlag Berger, 2014.

- Glaise-Horstenau, Edmund, Eduard Czegka, Maximilian Hoen, Rudolf Kiszling, Viktor Meduna-Riedburg, Eduard Steinitz, Ernst Wisshaupt in Georg Zöbl. Österreich-Ungarns Letzter Krieg 1914-1918, Band I. Wien: Verlag der Militärwissenschaftlichen Mitteilungen, 1931.

- Glaise-Horstenau, Edmund, Josef Brauner, Eduard Czegka, Jaromir Diakow, Friedrich Franek, Rudolf Kiszling, Eduard Steinitz in Ernst Wisshaupt. Österreich-Ungarns Letzter Krieg 1914-1918, Band II. Wien: Verlag der Militärwissenschaftlichen Mitteilungen, 1931.

35 Schildenfeld, Erzherzog Eugen, 8, 56, 65-72. Stummer, Erzherzog Eugen, 143, 166, 170, $243-$ 51, 283. 
- Held, Johannes. »Erzherzog Eugen von Österreich. Soldat-Ordensritter-Mäzen.« Doktorska disertacija, Universität Wien, 2010.

- Holler, Gerd. Franz Ferdinand von Österreich-Este. Wien: Verlag Carl Ueberreuter, 1982.

- Lukan, Walter. Iz "črnožolte kletke narodov« $v$ "zlato svobodo«?: Habsburška monarhija in Slovenci v prvi svetovni vojni. Ljubljana: Znanstvena založba Filozofske fakultete Univerze v Ljubljani, 2014.

- Nećak, Dušan in Božo Repe. O Feldmaršalu Svetozarju Boroeviću de Bojni. Ljubljana: Filozofska fakulteta Univerze v Ljubljani, 2010.

- Schildenfeld, Zoë von. Erzherzog Eugen 1863-1963. Innsbruck: Verlag Felizian Rauch, 1963.

- Simčič, Miro. Die Schlachten am Isonzo. 888 Tage Krieg im Karst in Fotos, Karten und Berichten. Graz: Leopold Stocker Verlag, 2003.

- Stergar, Rok. »«Politični cilji slovenske inteligence«: Nekaj o vohunih in vojakih.«Zgodovina za vse 5, št. 1 (1998): 21-29.

- Stummer, Rupert. Erzherzog Eugen 1863-1954. Salzburg: Österreichischer Milizverlag, 2009.

- Tigelhadt, Hptm. Mag. Alois. "Die Schlacht an der Kolubara."Zeitschrift der Offiziersgesellschaft Steiermark, 4/14 (2014): 14-15.

- Winter, O. F. »Sarkotić von Lovčen.«: V: Österreichisches Biographisches Lexikon, Band 9, 424-25. Wien: Verlag der Österreichischen Akademie der Wissenschaften, 1988.

- Wurmbrand, Ernst. Ein Leben für alt-Österreich. Ur. Lorenz Mikoletzky. Wien: Verlag Carl Ueberreuter, 1988.

Gregor Antoličič

ARCHDUKE EUGEN 1863-1954

S UMMARY

Archduke Eugen was born in 1863. His father was Karl Ferdinand of Austria, son of Karl of Austria who defeated Napoleon in the Battle of Aspern-Essling in 1809. Eugen's mother was Elisabeth of Austria, member of the Hungarian branch of the Habsburg family. Archduke Eugen had six siblings. The most famous of them was Maria Christina who married the Spanish King Alfonso XII in 1879. Eugen's father died when Eugen was eleven years old. Only three years later, at the age of fourteen, Archduke Eugen began his military career. In his long period of military service he was the only Austrian archduke who attended the k. u. k. Military school in Vienna. After many positions in different parts of the Austro-Hungarian Army he reached the rank of a major general in 1893. Only one year later Archduke Eugen became the $58^{\text {th }}$ Grandmaster of the Teutonic Order. He retained this function until 1923. As a Grandmaster he was committed to celibacy, which is the main reason why Archduke Eugen never had any descendants. In 1908 the emperor Francis Joseph proclaimed Archduke Eugen the chief military commander of Tyrol and Vorarlberg. In 1912 Archduke Eugen asked the Emperor for a one-year break from the military service. The main reason for this decision was Eugen's poor health (he had problems with his legs) as well as heir apparent Francis Ferdinand's jealousy. Although Eugen and Francis Ferdinand had a good relationship (Eugen visited Francis Ferdinand during his treatment in Egypt), the heir apparent was jealous of Eugen's extraordinary reputation. After the outbreak of World War I, Archduke Eugen became the Commander of the Balkan Front in late December 1914. His predecessor Oskar Potiorek, the Commander of the Austro-Hungarian Army in the Balkans since the beginning of the war, failed in all military actions against the Serbs and was sent into retirement. However, only a few months after Eugen became the Commander in the Balkans, the Kingdom of Italy declared war against Austro-Hungary. In this situation Archduke Eugen was proclaimed as the Commander of the SouthWest Front. The headquarters of this Command were established in the Slovenian city of Maribor. The Command stayed in Maribor until March 1916, and then returned to the city from March 1917 until November 1917. During this time, Svetozar Boroević von Bojna was the Commander of the $5^{\text {th }}$ Army, deployed at the Isonzo Front. Boroević disagreed with some of Eugen's orders, so he submitted a request for retirement to the Emperor and the Military Command. His request was denied. Although the relationship between Eugen and Boroević was not very good, they managed to avoid a major Italian 
invasion. After the Command of the South-West Front left Maribor in November 1917, it was dissolved in January 1918. At this point Archduke Eugen left the military service. After World War I and the collapse of the Habsburg Monarchy, Eugen lived in Switzerland between 1919 and 1934. Because of his respectable social status Archduke Eugen was allowed to return to Austria in 1934. He died in the city of Meran on 30 December 1954. 


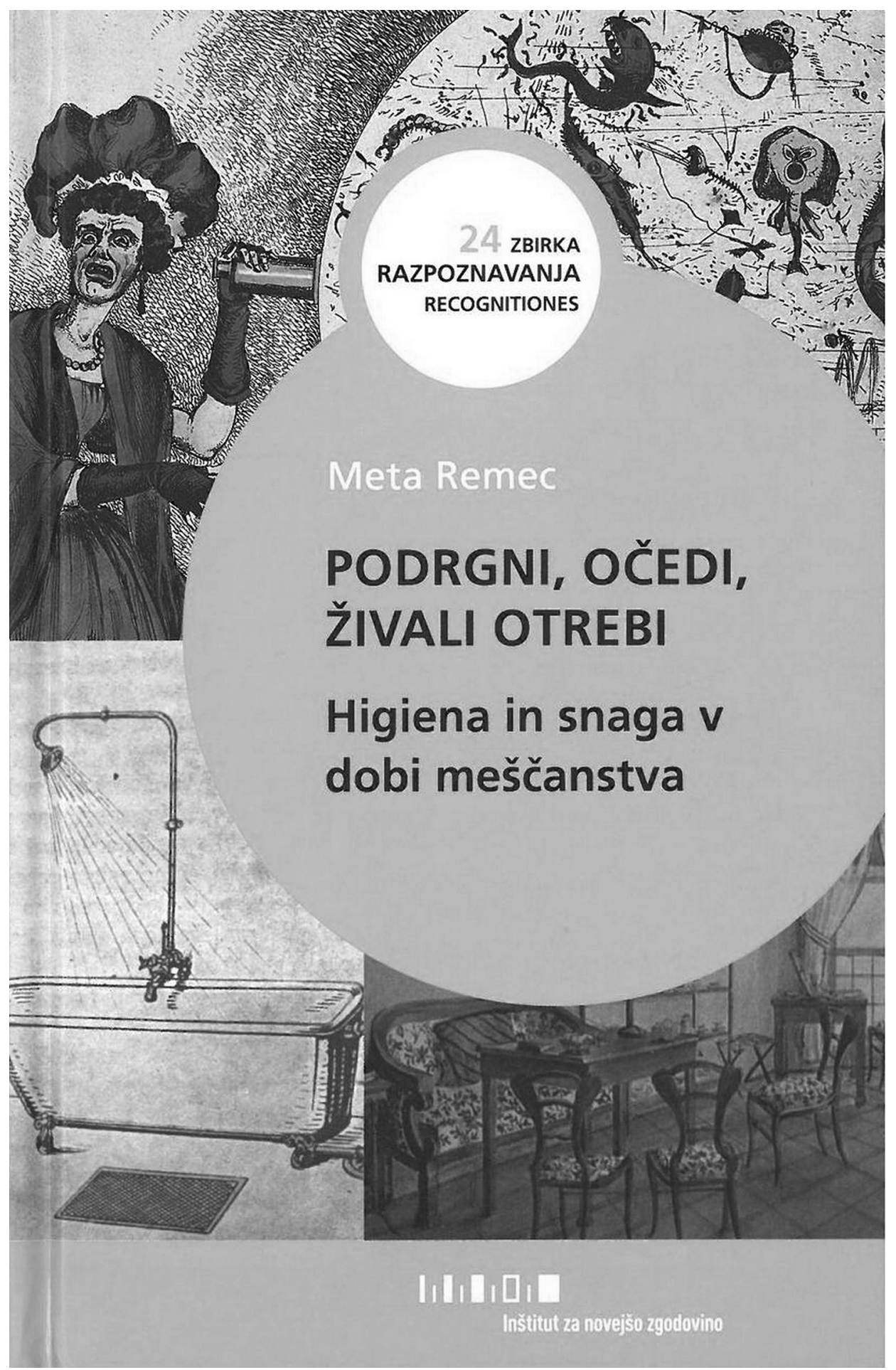

Cena: 24 EUR 